\title{
Factors Affecting Business Income of Empal Gentong in Cirebon City
}

\author{
By \\ Lathifa Dinar ${ }^{1 *}$ Neni Widayaningsih ${ }^{1)}$, Diah Setyorini Gunawan ${ }^{1)}$, Joseph Yakatambu Yaramai ${ }^{2)}$ \\ ${ }^{1)}$ Faculty of Economics and Business, Jenderal Soedirman University \\ ${ }^{2)}$ National Statistics Office, Papua New Guinea \\ ${ }^{*}$ Corresponding Author: dinarlathifa07@gmail.com
}

Submission: July 14, 2021; Accepted: September 30, 2021

\begin{abstract}
The goal of this research is to analyze the effect of capital, labor, length of business, education, and working hours on the empal gentong business income in Cirebon and to analyze which variable has the most effect on that income. We surveyed 30 business owners of empal gentong in Cirebon. The method using in this research is multiple linear regression. This result concludes capital, labor, length of business, education, and working hours have a positive and significant effect jointly on empal gentong business income. The analysis result in partially is capital and length of business have significant effect. Meanwhile, variables of labor, education and working hours have no significant effect on empal gentong business income. From these five variables, the most influential variable on empal gentong business income is the capital variable.
\end{abstract}

Keywords: Income, Capital, Labor, Length of Business, Education, Working Hours

\begin{abstract}
ABSTRAK
Tujuan dalam penelitian ini yaitu menganalisis dampak modal, tenaga kerja, lama usaha, pendidikan, dan jam kerja terhadap pendapatan usaha empal gentong, dan menganalisis variabel mana yang memiliki pengaruh paling besar. Kami telah mensurvei responden terdiri dari 30 pengusaha empal gentong. Untuk mengetahui dampak seluruh variabel menggunakan metode regresi linear berganda. Hasil penelitian menunjukan bahwa variabel modal, tenaga kerja, lama usaha, pendidikan, dan jam kerja berpengaruh positif dan signifikan secara bersama-sama terhadap pendapatan pengusaha empal gentong di Kota Cirebon. Sedangkan untuk hasil analisis masing-masing variabel menunjukan bahwa modal dan lama usaha berpengaruh secara positif dan signifikan. Untuk variabel tenaga kerja, pendidikan dan jam kerja tidak berpengaruh secara signifikan terhadap pendapatan pengusaha empal gentong di Kota Cirebon. Dari ke-lima variabel yang paling berpengaruh terhadap pendapatan pengusaha empal gentong di Kota Cirebon adalah variabel modal.
\end{abstract}

Kata Kunci: Pendapatan, Modal, Tenaga Kerja, Lama Usaha, Pendidikan, Jam Kerja

\section{INTRODUCTION}

Economic development aims to increase per capita income, and also to ensure an equitable distribution of income for the whole society. Economic development, such as a city or a country can be measured by increasing the production of goods and services and can also be seen from changes in several other economic aspects, such as improvements in technology, education, improvements in health, infrastructure development, and increased income and prosperity of the community (Sukirno, 2015).

Increasing economic development in a country can be through the role of entrepreneurs in the economic activities of a country. This statement is in line with the opinion of Todaro (2012), which 
states that development is a process that may consist of various aspects such as changing in people's attitudes and behavior, changing in social structures, as well as handling income inequality and poverty alleviation. In addition to increase economic development, entrepreneurs can also offer job opportunities for the surrounding community, this can reduce the existing unemployment rate.

Economic development in a country can be seen from the role of Micro, Small and Medium Enterprises (MSMEs). MSMEs are seen as one of the indicators that have an important role in the Indonesian economy. Forms of Micro, Small and Medium Enterprises (MSMEs) are Individual Companies, Civil Partnerships, Firm Partnerships and Limited Partnerships (CV), and Limited Liability Companies (PT). The category of MSMEs based on total assets and turnover can be categorized into 3 , namely micro, small and medium enterprises (Undang-Undang No. 20 Tahun 2008).

Table 1. Number of MSMEs and Labor in Indonesia, 2014-2018

\begin{tabular}{lrrrrr}
\hline & \multicolumn{1}{c}{2014} & \multicolumn{1}{c}{2015} & \multicolumn{1}{c}{2016} & \multicolumn{1}{c}{2017} & \multicolumn{1}{c}{2018} \\
\hline MSMEs (units) & 56.534 .592 & 59.262 .772 & 61.651 .117 & 62.922 .617 & 64.197 .057 \\
Labor (people) & 107.657 .509 & 123.229 .387 & 112.828 .610 & 116.431 .224 & 116.9778 .631 \\
\hline
\end{tabular}

Source: Ministry Of Cooperatives and SMEs of The Republic of Indonesia 2019

In 2014-2018 the number of MSMEs in Indonesia has increased. The contribution of MSMEs to the labor absorption rate in 2018 was around 96 percent of the entire national manpower (Central Agency on Statistics, 2019). The number of businesses or companies on the island of Java contributes 60.74 percent in Indonesia and the distribution of the workforce is 63.38 percent of the national figure. The spread of business in West Java province is 28.57 percent or as many as 4,599,247 businesses of the number of businesses on the island of Java which places second after East Java province, which is 4,618,283 businesses (Economic Census, 2016).

The number of businesses in West Java province contributes 17.35 percent to the national figure and is able to absorb around 16.17 percent of the national workforce (Economic Census, 2016). One of the cities with the lowest MSME contribution in West Java province is Cirebon City with a percentage of 0.87 percent of the total business in West Java. The number of MSMEs in Cirebon City in 2016 was 38,485 units with a total workforce of 90,196 people (Economic Census, 2016).

One of the MSMEs in West Java is a culinary business. West Java is known as a province with various types of culinary (Rahmawati and Maharani, 2014). Some examples of culinary delights in West Java are sate maranggi, mie koclok, and empal gentong. Empal gentong is a traditional food from one area in West Java, which is Cirebon.

Cirebon city is known as a place with variety of a variety of traditional foods that are often found such as empal gentong, nasi jamblang and tahu gejrot. Empal gentong is a soupy food that resembles opor and is cooked in a barrel. Because, in ancient times there were no cooking utensils such as pots, so people used clay barrels for cooking. Empal gentong is a culinary made from beef cooked with firewood and other spices (Anisah, 2017). Empal gentong business is different from other Cirebon culinary businesses because this business is not a peddler. This empal gentong business is in the form of a restaurant or already has its own trading place.

The multitude amount of similar businesses have been the cause of fierce competitions. So that it can affect the income of the entrepreneurs themselves. Income is all earnings in the form of money or goods, whether originating from other parties or business results, which are valued at a sum of money from the current assets. Income is the remuneration obtained by the community from the production factors donated within a certain period of time (Reksoprayitno, 2010).

This is different from previous research conducted by Wachdijono (2017) which discussed consumer preferences of empal gentong and research by Anisah (2017) regarding customer satisfaction of empal gentong. This study examines the factors that affect the income of Empal Gentong entrepreneurs in Cirebon City. According to researches by Dewi (2019) and Butarbutar et al (2017), variables of capital, labor, and length of business have a positive and significant effect to business income. 


\section{METHODS}

The research was conducted through survey by conducting direct interviews with respondents using questionnaires. The respondents in this research were empal gentong entrepreneurs in Cirebon City, West Java.

The research used multiple linear regression analysis with ordinary least square method which is used to test the income model. The general form of regression analysis was as follows:

$$
\mathrm{Y}_{\mathrm{i}}=\alpha+b_{1} \mathrm{X}_{1 \mathrm{i}}+b_{2} \mathrm{X}_{2 \mathrm{i}}+b_{3} \mathrm{X}_{3 \mathrm{i}}+b_{4} \mathrm{X}_{4 \mathrm{i}}+b_{5} \mathrm{X}_{5 \mathrm{i}}+e
$$

In the research, multiple linear equations were transformed into multiple linear regression equations with a double linear logarithm model that can determine which variables have the most influence, as follows:

Notes:

$$
\operatorname{Ln} Y_{i}=\alpha+b_{1} \ln X_{1 i}+b_{2} \ln X_{2 i}+b_{3} \ln X_{3 i}+b_{4} \ln X_{4 i}+b_{4} \ln X_{5 i}+e
$$

$\operatorname{LnY}_{i} \quad=$ Income of empal gentong entrepreneurs in Cirebon City

$\alpha=$ Constant

$B_{1} \quad=$ Regression coefficient of capital (X1)

$B_{2} \quad=$ Regression coefficient of labor (X2)

$B_{3} \quad=$ Regression coefficient of length of business (X3)

$B_{4} \quad=$ Regression coefficient of education (X4)

$B_{5} \quad=$ Regression coefficient of working hours (X5)

$\mathrm{X}_{1 \mathrm{i}} \quad=$ Capital

$\mathrm{X}_{2 \mathrm{i}} \quad=$ Labor

$X_{3 i} \quad=$ Length of business

$\mathrm{X}_{4 \mathrm{i}}=$ Education

$X_{5 i} \quad=$ Working hour

e $\quad=$ Error

To analyze the effect of capital, labor, length of business, education and working hours jointly and partially on the income of empal gentong entrepreneurs in Cirebon City, the research used hypothesis testing, namely F-est, t-test, and determination test. Meanwhile, to analyze the variables which has the greatest influence, it used the elasticity test. However, it's model has been in double linear logarithm form so the most influential variable can be determined by interpreting each variable coefficient.

\section{RESULT AND DISCUSSION}

This research used multiple linear regression analysis technique. The dependent variable was income of empal gentong entrepreneurs in Cirebon City $(\mathrm{Y})$ while the independent variables were capital $\left(\mathrm{X}_{1}\right)$, labor $\left(X_{2}\right)$, length of business $\left(X_{3}\right)$, education $\left(X_{4}\right)$, and working hours $(X 5)$. The data of this research was analyzed by SPSS 25 .

Table 2. Multiple Linear Regression Test Result

\begin{tabular}{crc}
\hline Variable & Coefficient & Sig. \\
\hline $\mathrm{C}$ & 8.400 & 0.000 \\
$\operatorname{LnX}_{1}$ & 0.552 & 0.000 \\
$\operatorname{LnX}_{2}$ & 0.251 & 0.242 \\
$\operatorname{LnX}_{3}$ & 0.547 & 0.001 \\
$\operatorname{LnX}_{4}$ & 0.598 & 0.176 \\
$\operatorname{LnX} X_{5}$ & -1.498 & 0.005 \\
\hline
\end{tabular}

Source: Processed data by researcher, 2021

Based on multiple linear regression analysis on SPSS 25 , the following results were obtained: $\operatorname{LnY}=8,400+0,552 \ln \mathrm{X}_{1 \mathrm{i}}+0,251 \ln \mathrm{X}_{2 \mathrm{i}}+0,547 \ln \mathrm{X}_{3 \mathrm{i}}+0,598 \ln \mathrm{X}_{4 \mathrm{i}}-1,498 \mathrm{X}_{5 \mathrm{i}}+e$ 
Classical assumption test consists of normality test, multicollinearity test, heteroscedasticity test, and autocorrelation test. In this research, normality test was done using the KolmogorovSmirnov. If the significance value is more than 0.05 , then the data is normally distributed, while if the significance value is less than 0.05 , then it is not normally distributed.

Table 3. Normality Test Result

$\begin{array}{cl}\text { Test Statistic } & 0.147 \\ \text { Asymp. Sig } & 0.95\end{array}$

Source: Processed data by researcher, 2021

Table 3 it can be seen that asymptotic significance shows 0.95 which is more than 0.05 and meaning that the variable data is normally distributed.

Table 4. Multicollinearity Test Result

\begin{tabular}{cccc}
\hline Variable & Coefficient & Tolerance & Statistics VIF \\
\hline C & 8.400 & & \\
$\operatorname{LnX}_{1}$ & 0.552 & 0.455 & 2.198 \\
$\operatorname{LnX} 2$ & 0.251 & 0.372 & 2.687 \\
$\operatorname{LnX}_{3}$ & 0.547 & 0.740 & 1.351 \\
$\operatorname{LnX} 4$ & 0.598 & 0.628 & 1.592 \\
$\operatorname{LnX} X_{5}$ & -1.498 & 0.526 & 1.901 \\
\hline
\end{tabular}

Source: Processed data by researcher, 2021

Multicollinearity test was measured by Variance Inflation Factor (VIF). If the VIF value of each independent variable is less than 10, then there is no multicollinearity. Based on the result, the VIF value of each variable is less than 10 , then the model has no multicollinearity problem.

Table 5. Heteroscedasticity Test Result

\begin{tabular}{cccc}
\hline Variable & Coefficient & t-Statistic & Sig. \\
\hline C & 0.722 & 0.861 & 0.398 \\
$\operatorname{LnX}_{1}$ & 0.085 & 1.807 & 0.083 \\
$\operatorname{LnX}_{2}$ & 0.102 & 0.873 & 0.391 \\
$\operatorname{LnX}_{3}$ & -0.043 & -0.560 & 0.580 \\
$\operatorname{LnX}_{4}$ & -0.354 & -1.477 & 0.153 \\
$\operatorname{LnX}$ & -0.349 & -1.299 & 0.206 \\
\hline
\end{tabular}

Source: Processed data by researcher, 2021

In the research, the heteroscedasticity test used Glejser test, with the criteria that if the level of significance is more than 0.05 , then the research model has no problem of heteroscedasticity. The data contained in the table stated the level of significance for each variable is more than 0.05 . Thus, this research has no problem of heteroscedasticity.

Table 6. Autocorrelation Test Result

\begin{tabular}{cc}
\hline Adjusted R Square & 0.831 \\
Durbin-Watson & 2.091 \\
\hline
\end{tabular}

Source: Processed data by researcher, 2021

The autocorrelation test in the research used Durbin-Watson test, with the criteria that the Durbin-Watson value was at $d_{u}<d<4-d_{u}$. To find out whether the Durbin-Watson value is between 
$d_{u}<d<4-d_{u}$, it can be seen in the Durbin-Watson table. In this research, the $d_{u}$ value of 30 respondents and 5 variables is at a value of 1.8326. With a value of $4-d_{u}=2.1674$. As seen in Table 6 , the DurbinWatson value was 2.091 which is between 1.8326 and 2.1674 . So, it can be said that the data in this research has no autocorrelation problems.

To test whether the variables of capital, labor, length of business, education, and working hours have joint effect on the income variable, it used F-Test. The results of the F-test can be seen in the following table:

Table 7. F-test Result

\begin{tabular}{cr}
\hline F Statistic & 29.544 \\
Sig. & 0.000 \\
\hline
\end{tabular}

Source: Processed data by researcher, 2021

It can be seen in Table 7 that the $F$ statistic value is 29.544 . It means that the $F$ statistic value was more than $\mathrm{F}$ table value. With a significance level of 0.000 or less than 0.05 , it could be concluded that the variables of capital, labor, length of business, education, and working hours affected the income of the empal gentong entrepreneurs jointly.

To test how each independent variable affects the dependent variable, $t$-test was performed. The following were the result of the t-test in this research:

Table 8. $\mathrm{t}$-Test Result

\begin{tabular}{cccc}
\hline Variable & Coefficient & t-Statistic & Sig. \\
\hline$C$ & 8.400 & 5.606 & 0.000 \\
$\operatorname{LnX} X_{1}$ & 0.552 & 6.598 & 0.000 \\
$\operatorname{LnX}_{2}$ & 0.251 & 1.200 & 0.242 \\
$\operatorname{LnX}_{3}$ & 0.547 & 3.953 & 0.001 \\
$\operatorname{LnX} X_{4}$ & 0.598 & 1.393 & 0.176 \\
$\operatorname{LnX} X_{5}$ & -1.498 & -3.117 & 0.005 \\
\hline
\end{tabular}

Source: Processed data by researcher, 2021

In the capital variable. the $t$-statistic value were 6.598 and the significance level was 0.000 . The regression coefficient of the capital was 0.552 . If capital increases by one percent. then income would increase by 0.552 percent assuming other variables remained constant. So that capital has a positive and significant effect on the income of empal gentong entrepreneurs in Cirebon City. The use of higher capital would have a positive effect on the income received (Riyanto. 2014). If empal gentong entrepreneurs in Cirebon City use high capital. it can be used to increase their production factors so that the income earned by entrepreneurs also increases. This research is supported by research conducted by Dewi (2019) and Polandos et al. (2019) which stated that capital had a positive and significant effect on income.

In the labor variable. the t-statistic value was 1.200 and the significance value was 0.242 . The regression coefficient of labor was 0.251 . If the labor increases by one percent. then income would increase by 0.251 percent assuming other variables remained constant. So that the labor variable does not affect the income of empal gentong entrepreneurs in Cirebon City. As the number of workers increases. income and productivity would also increase (Sukirno. 2015). However. the research was not in line with that. The results of this research were in line with research conducted by Kusuma (2019) which stated that the labor variable had no significant effect on income.

In the variable length of business. the t- statistic value was 3.953 and the significance value was 0.001 . The regression coefficient of the length of business was 0.547 . If the length of business increases by one percent. the income would increase by 0.547 percent with the assumption that other variables were constant. So that the length of business had a positive and significant effect on the income of entrepreneurs of empal gentong in the Cirebon City. The length of business had an impact 
on increasing business experience. and experience could have an impact on a person's view of behavior (Sukirno. 2015). The results of this research were in line with research conducted by Butarbutar et al (2017) which said that the length of business had a positive and significant effect on income.

In the education variable. the t-statistic value was 1.393 and the significance value was 0.176 . The regression coefficient of education was 0.598 . If education increased by one percent. income would increase by 0.598 percent with the assumption that other variables were constant. Education had no effect on the income of empal gentong entrepreneurs in Cirebon City. The results of this research were in line with the research conducted by Maheswara et al (2016) which stated that education has no positive and significant effect on income.

In the working hours variable. the t-statistic value was -3.117 and the significance value is 0.005. Working hours had a negative and significant effect on the income of empal gentong entrepreneurs in Cirebon City. Increased working hours had no effect on income. The results of this research were in line with the research of Prihatminingtyas (2019) which stated that working hours had a negative effect on income.

Table 9. Determination Test Result

\begin{tabular}{cc}
\hline$R$ & 0.927 \\
R Square & 0.860 \\
Adj. R Square & 0.831 \\
\hline
\end{tabular}

Source: Processed data by researcher, 2021

The value of adjusted $R$ square was 0.831 . which means that variation of the income variable could be explained by the variation of capital. labor. length of business. education. and working hours of 83.1 percent.

The significance and the regression coefficient value of the capital variable had a higher value than the variables of labor. length of business. education. and working hours (E1 > E2. E3. E4. E5). So that the capital variable was the variable that had the greatest influence on the income of the empal gentong entrepreneurs in the Cirebon City. This proves that the use of larger initial capital would increase the income earned by entrepreneurs. Income could be increased by the use of production factors. one of which is capital (Suparmoko. 2012). The results of this research had similarities with research conducted by Polandos et al (2019) and Diandrino (2018) which said that capital was the variable that had the most influence on operating income.

\section{CONCLUSION}

Based on the results, it showed that the variables of capital. labor. length of business. education. and working hours have positive and significant effect jointly on the income of Empal Gentong entrepreneurs in Cirebon City. Meanwhile. the results of each analysis showed that capital and length of business had a positive and significant effect partially. The variables of labor. education and working hours have no significant effect the income of empal gentong entrepreneurs in Cirebon City. Among the five independent variables the most influential is capital.

The implication can be suggested was that entrepreneurs can increase their capital by making loans because capital was the most influential factor. Besides that, entrepreneurs can train the workforce to be more skilled, maintain the quality of their products, take a part in MSME innovation training held by related parties, and can better adjust consumers in determining business hours.

\section{REFERENCES}

Anisah, A. A., (2017). Analisis Pengukuran Tingkat Kualitas Pelayanan terhadap Kepuasan Pelanggan Dengan Metode Service Quality (SERVQUAL) (Studi Kasus Pada "UKM EMPAL GENTONG AMARTA" Cirebon-Jawa Barat). 1-2.

Badan Pusat Statistik. (2016). Sensus Ekonomi 2016. Jakarta: Badan Pusat Statistik. Retrieved from https://se2016.bps.go.id/umkumb/ Acessed on 2021, January 18. 
. (2019). Statistik Pendidikan Indonesia 2018. Jakarta: Badan Pusat Statistik. Retrieved from https://www.bps.go.id/publication/...statistik-pendidikan-2018/. Acessed on 2021, January 18

Butarbutar, G. R., Widayatsari, A., dan Aqualdo, N. (2017). Analisis Faktor-Faktor yang Mempengaruhi Pendapatan Usaha Industri Makanan Khas di Kota Tebing Tinggi.

Dewi, N. P. M., \& Utari, T. (2014). Pengaruh modal, tingkat pendidikan dan teknologi terhadap pendapatan usaha mikro kecil dan menengah (UMKM) di Kawasan Imam Bonjol Denpasar Barat. E-Jurnal Ekonomi Pembangunan Universitas Udayana, 3(12), 44496.

Diandrino, D. (2018). Analisis Faktor-Faktor Yang Mempengaruhi Pendapatan UMKM Kedai Kopi Di Kota Malang. Jurnal Ilmiah Mahasiswa FEB. 6(2).

Kusuma, C. (2019). Effect of Capital, Technology, Labor, and Production of Revenues. Technology, Labor, and Production of Revenues (December 30, 2019).

Kementerian Koperasi dan Usaha Kecil dan Menengah RI. (2018). Perkembangan Data Usaha Mikro, Kecil, Menengah (UMKM) Dan Usaha Besar (UB) Tahun 2017-2018. Jakarta, DKI:Penulis. Retrieved from http://www.depkop.go.id/uploads/laporan/....pdf. Acessed on 2020, November 16.

Maheswara, A. A. N. G., Setiawina, N. D., \& Saskara, I. A. N. (2016). Analisis Faktor-Faktor Yang Mempengaruhi Pendapatan UKM Sektor Perdagangan Di Kota Denpasar. E-Jurnal Ekonomi dan Bisnis Universitas Udayana. 5(2016), 4271-4298.

Polandos, P. M., Engka, D. S., dan Tolosang, K. D. (2019). Analisis Pengaruh Modal, Lama Usaha, Dan Jumlah Tenaga Kerja Terhadap Pendapatan Usaha Mikro Kecil Dan Menengah Di Kecamatan Langowan Timur. Jurnal Berkala IImiah Efisiensi. 19(04).

Prihatminingtyas, B. (2019). Pengaruh Modal, Lama Usaha, Jam Kerja Dan Lokasi Usaha Terhadap Pendapatan Pedagang Di Pasar Landungsari. Referensi: Jurnal Ilmu Manajemen dan Akuntansi. 7(2), 147-154.

Rahmawaty, U., dan Maharani, Y. (2014). Pelestarian Budaya Indonesia Melalui Pembangunan Fasilitas Pusat Jajanan Tradisional Jawa Barat. Interior Design. 2(1).

Reksoprayitno. (2010). Sistem Ekonomi dan Demokrasi Ekonomi. Jakarta:Bina Grafika

Riyanto, B. (2014). Pembelanjaan Perusahaan. Yogyakarta: BPFE

Sukirno, S. (2015). Makroekonomi: Teori Pengantar (Edisi 5). Jakarta: Rajawali Press.

Todaro, M. P. (2012). Pembangunan Ekonomi di Dunia Ketiga. Jakarta : Erlangga.

Undang-Undang Nomor 20 Tahun 2008 Tentang Usaha Mikro, Kecil, dan Menengah

Wachdijono. (2017). Preferensi Konsumen Terhadap Empal Gentong Di Desa Battembat Kecamatan Tengah Tani Kabupaten Cirebon Provinsi Jawa Barat. Forum Keuangan dan Bisnis Indonesia (FKBI). 6(1), 479-490. 